\title{
Use of alternative medicine, ginger and licorice among Danish pregnant women - a prospective cohort study
}

Tabia Volqvartz ${ }^{1,2}$, Anna Louise Vestergaard ${ }^{1,2}$, Sissel Kramer Aagaard ${ }^{1,2}$, Mette Findal Andreasen ${ }^{3}$, lana Lesnikova ${ }^{4}$, Niels Uldbjerg ${ }^{5}$, Agnete Larsen ${ }^{2}$ and Pinar Bor ${ }^{1 *}$

\begin{abstract}
Background: The use of alternative medicines and dietary supplements is constantly changing, as are dietary habits. One example of this phenomenon is the current popularity of ginger products as an everyday health boost. Ginger and licorice has also been shown to ameliorate nausea a common complaint in early pregnancy. Alternative medicines are often regarded as safe. However, they might affect fetal development, such as through alterations of hormone metabolism and cytochrome P450 function. Health care professionals may be unaware of the supplementation habits of pregnant women, which may allow adverse exposures to go unnoticed, especially if the rates of use in pregnancy are not known. We therefore investigated the use of alternative medicines and licorice among pregnant Danish women.

Methods: A total of 225 pregnant women were included in a prospective cohort when attending the national prenatal screening program at gestational weeks 10-16. Participants were asked to complete a questionnaire regarding their socio-economic status and lifestyle habits, including their intake of alternative medicine and licorice.

Results: We found that $22.7 \%$ of women reported taking alternative medicines, with $14.7 \%$ reporting daily consumption. Ginger supplements were consumed by $11.1 \%$, mainly as health boost and $87.1 \%$ reported consumption of licorice. Regular or daily licorice consumption was reported by 38.2 and $7.1 \%$, respectively. Notably, the use of licorice was reflected by an increase in blood pressure of the pregnant women.

Conclusions: The use of licorice and alternative medicines appears to be common in pregnant Danish women, supporting the need for further investigations into the safety of alternative medicine use during pregnancy and the importance of up-to-date personalized counseling regarding popular health trends and lifestyle habits.
\end{abstract}

Keywords: Alternative medicine, First trimester pregnancy, Ginger, Herbal medicine, Licorice

\section{Background}

In modern society, everyday lifestyles are constantly changing. With the plethora of internet-based platforms, new health trends can spread rapidly among pregnant women. Such habits may escape the attention of health care professionals, allowing adverse exposures in early pregnancy to go undetected. International data supports the hypothesis that pregnant women perceive herbal and conventional medications as quite harmless [1].

\footnotetext{
* Correspondence: isipinbo@rm.dk; isibor@rm.dk

Tabia Volqvartz and Anna-Louise Vestergaard shared first authorship

Agnete Larsen and Pinar Bor shared senior authorship

'Department of Obstetrics and Gynecology, Randers Regional Hospital,

Randers, Denmark

Full list of author information is available at the end of the article
}

Moreover, a recent study reported that recommendations to take contra-indicated herbal medicines during pregnancy may come directly from health care professionals [2].

A multinational study from 2016 suggested that up to $60 \%$ of all pregnant women use herbal-based alternative medicines [2]. However, cultural differences in the use of alternative medicine are well-established, even within the Scandinavian and Nordic countries. In Iceland, the prevalence has been reported to be as high as $35 \%$, in contrast to Norway and Sweden where the prevalence has been reported to be 17 and $4 \%$, respectively [3]. However, the prevalence of such use among pregnant women in Denmark has not previously been published.

(c) The Author(s). 2019 Open Access This article is distributed under the terms of the Creative Commons Attribution 4.0 International License (http://creativecommons.org/licenses/by/4.0/), which permits unrestricted use, distribution, and reproduction in any medium, provided you give appropriate credit to the original author(s) and the source, provide a link to the Creative Commons license, and indicate if changes were made. The Creative Commons Public Domain Dedication waiver (http://creativecommons.org/publicdomain/zero/1.0/) applies to the data made available in this article, unless otherwise stated. 
Importantly, the safety of many herbal remedies has never been investigated in human pregnancies, as no strict rules for safety testing apply to alternative medicine [4] despite their teratogenic potential [5]. Several adverse effects caused by alternative medicine in pregnancy have been described, including miscarriage, preterm delivery, and malformations. Interestingly, recent data suggest that between $2.5-13 \%$ of pregnant women use alternative medicines together with prescribed medications [6]. However, there are limited published data investigating the adverse effects of alternative medicine due to their direct chemical toxicity, herbal-drug or herbal-herbal interactions.

Studies have shown that the majority (76\%) of women who self-administer herbal medicine during pregnancy do not disclose their use to their doctor or midwife [7], making such use a potential safety concern.

Common exposure during pregnancy includes the use of ginger, which for decades has been the most widely used herbal remedy in the management of pregnancy-related nausea and vomiting. In addition, ginger is thought to strengthen the immune system and generally boost human health, leading to an increased popularity in recent years. At present, ginger is often added to consumables routinely sold in Danish supermarkets, such as teas and shots. The use of ginger as a health booster could lead to increased and continuous consumption throughout pregnancy, yet no guidelines currently exist in relation to the permissible amount of ginger exposure, even though ginger as a dietary supplement is not recommended by the Danish Veterinary and Food Administration. Several studies have found occasional use of ginger as an anti-emetic to be safe [8]. However, recent reports have shown that pharmacologically active substances in ginger may increase the risk of bleeding by decreasing platelet aggregation [9], and ginger-based compounds have been suspected to increase the risk of stillbirth [10]. If unaware of these potential risk pregnant women might continue their ginger habits throughout pregnancy - in particular if also obtaining a reduction of nausea that might give them the impression that ginger is well-tolerated by the body. Originally, licorice was used against upper respiratory problems and stomach inflammation while today it is primarily eaten for pleasure. However, a double-blind randomized study found a positive effect of licorice in prevention of acid reflux and vomiting [11]. Nausea and vomiting are common complains during pregnancy underlining that eating habits may also reflect a subconscious "self-medication" strategy in particular in Scandinavia were licorice based candies are well-known and popular. However, licorice can increase blood pressure, and the content of glycyrrhizin - the major active constituents of licorice - can also decrease platelet aggregation [12] making it a key problem that several candy products with licorice is increasingly being consumed during pregnancy.

As a systematic report of the current use of licorice, alternative medicines and other herbal supplements among pregnant Danish women has never been reported, the aim of this study was to assess the prevalence and characteristics of alternative medicine, ginger and licorice use among Danish pregnant women.

\section{Methods}

In this prospective cohort study, we included participants seen at the Department of Obstetrics and Gynecology, Randers Regional Hospital, Denmark between June 2016 and December 2016. The inclusion criteria was attendance at a routine ultrasound examination in gestational week 10-16, which is accepted by more than $95 \%$ of the pregnant women in the recruitment area where this scan is not offered elsewhere. Exclusion criteria included an age below 18 years and poor language skills.

The study was approved by the Regional Scientific Ethical Committee (VEK 1-10-72-75-16) and followed the Helsinki guidelines of informed consent. Due to additional obligations, we could only recruit participants 2 3 days a week. On these days all eligible women were invited in correlation with their random given times at the ultrasound unit (Table 1).

The participants answered a questionnaire at recruitment or during a phone call within 1-2 weeks regarding the following information: age, parity, Body Mass Index (BMI), smoking, alcohol, licorice intake, socio-economic status, educational level, use of prescription and over the counter medicine (OTC), supplemental vitamins, and intake of alternative medications including herbal supplements (e.g., teas). If the women used any health supplements or followed a specific nutritional lifestyle, they were asked to specify the amount and duration of the various intakes. After delivery, we obtained information regarding outcomes from the women's electronic medical records (Additional file 1: Table S2).

\section{Statistics}

Continuous variables were compared between groups using Student's tests or Mann-Whitney testing based on the testing of normal distribution of the data. Two-tailed comparisons were performed unless otherwise noted. Data are summarized as the means \pm SD. GraphPad Prism version 7.03 Software (GraphPad Software, Inc., San Diego, CA, USA) was used to analyse the Student's t-test and Mann-Whitney test results as well as confidence intervals presented in the relevant Tables. A level of significance at or below 0.05 was considered statistically significant for all analyses. 
Table 1 Demographic characteristics of the cohort

\begin{tabular}{|c|c|}
\hline Demography & $\%(n)$ \\
\hline \multicolumn{2}{|l|}{ Maternal age (years) } \\
\hline $20-29$ & $50.9(114)$ \\
\hline $30-39$ & $44.6(100)$ \\
\hline$\geq 40$ & $4.5(10)$ \\
\hline \multicolumn{2}{|l|}{ Parity } \\
\hline Nulliparous & $41.5(93)$ \\
\hline Primiparous & $44.6(100)$ \\
\hline Multiparous & $13.8(31)$ \\
\hline \multicolumn{2}{|l|}{ Maternal pre-pregnancy BMI (kg/m2) } \\
\hline Underweight $(<18,5)$ & $1.8(4)$ \\
\hline Normal $(18,5-24,9)$ & $43.3(97)$ \\
\hline Overweight (25-30) & $29.9(67)$ \\
\hline Obese (> 30) & $25.0(56)$ \\
\hline Chronic health issues & $28.6(64)^{a}$ \\
\hline No chronic health issue & $71.4(160)$ \\
\hline Married & $42.0(94)$ \\
\hline In relationship, cohabitating & $54.0(121)$ \\
\hline In relationship, non-cohabitating & $2.2(5)$ \\
\hline Single & $1.3(3)$ \\
\hline Other & $0.4(1)$ \\
\hline \multicolumn{2}{|l|}{ Highest completed education level } \\
\hline Elementary school & $3.6(8)$ \\
\hline Upper secondary school & $7.6(17)$ \\
\hline Vocational education & $25.0(56)$ \\
\hline Shorter level of education & $12.9(29)$ \\
\hline Bachelor degree & $37.9(85)$ \\
\hline Master degree & $12.1(27)$ \\
\hline Other & $0.9(2)$ \\
\hline \multicolumn{2}{|l|}{ Household income } \\
\hline$<103,000$ DKK & $0.9(2)$ \\
\hline 103,000-200,000 DKK & $3.6(8)$ \\
\hline 200,000-500,000 DKK & $35.3(79)$ \\
\hline $500,000-800,000$ DKK & 46.4 (104) \\
\hline$>800,000$ DKK & $13.8(31)$ \\
\hline
\end{tabular}

${ }^{a}$ Chronic health issues were self-reported, such as asthma and allergies, metabolic disorders, dermatitis, cardiovascular disorders, bowel disorders, autoimmune disorders and previous cancers

\section{Results}

Among 297 eligible Danish women attending a routine first trimester ultrasound scan during our presence, we included 225 (75.8\%) women who accepted to participate in the study, corresponding to a prevalence of $23.1 \%$ of all birth at Randers Regional Hospital in the inclusion period. Lack of time was the most common reason given for non-participation.
All women were interviewed, all but one returned the completed questionnaire living a study population for this study of 224 .

The vast majority $71.8 \%(n=158)$ had a spontaneous vaginal delivery (for details on birth complications and new born Apgar score see Additional file 1: Table S2). Of the 224 women from whom questionnaire data were available, data on birth weight and infant health was available from 217 participants. Of the seven missing individuals, four had a spontaneous abortion (1.8\%), and three $(1.3 \%)$ were lost to follow up at birth, because they had moved to another district (Additional file 2: Figure S1). Information regarding the correspondence between exposures and outcome was based on the 217 women that gave birth at Randers Regional Hospital. (For details on parity and lifestyle see Additional file 3: Table S1).

Up to $22.7 \%(n=51)$ reported consumption of at least one type of alternative medicine, $14.7 \%(n=33)$ reported doing so daily, and $4.9 \%(n=11)$ took more than one remedy regularly. This intake was associated with chronic health issues $(31.3 \%$; 20 of 64$)$, of which the majority reported a daily use $(20.0 \%$; 13 of 65$)$, and a high household income (32.3\%; 10 of 31; Table 2).

Ginger products were the most frequently used form of alternative medicine $(11.1 \%, n=25)$, such as through shots $(7.1 \% ; n=16)$, tea, tablets, and oil. Among these, $3.1 \%(n=7)$ reported taking them alongside prescription or OTC medicine. Only $2.7 \%(n=6)$ used ginger for nausea and vomiting. The intake of ginger products was associated with chronic health issues $(17.2 \%$; 11 of 64$)$, mean maternal age 31.8 years (95\% CI: 29.9-33.6) among users vs. 29.5 years (95\% CI: 28.6-30.1) among non-users $(p=0.02)$, mean birthweight $3572 \mathrm{~g}$ (95\% CI: 3316-3827 g) among exposed vs. $3440 \mathrm{~g}(95 \% \mathrm{CI}$ : $3355-3525 \mathrm{~g})$ among unexposed $(p=0.28)$. Additionally, the consumption rate of ginger increased with higher levels of education, lowest among women with an upper secondary school education $(5.9 \% ; 1$ of 17$)$ and highest among women with a master's degree (14.8\%; 4 of 27).

Other frequently used products included peppermint tea for nausea $(1.8 \% ; n=4)$, Psyllium Husk Fiber ${ }^{\odot}$ for obstipation $(6.7 \% ; n=15)$, and Kräuterblut ${ }^{\odot}$ as an herbal substitute for iron supplements $(2.7 \% ; n=6)$, see Table 3 and Table 4.

No less than $87.1 \%(n=196)$ reported consuming licorice, $38.2 \%(n=86)$ reported licorice consumption at least "a couple of times a week," and 7.1\% $(n=16)$ reported daily use. On each occasion of consumption, $33.8 \%(n=76)$ ate at least a handful of licorice candies, and $4.4 \%(n=10)$ reported consuming an entire bag of licorice. All participants with hypertension $(1.3 \% ; n=3)$ reported a weekly consumption of licorice. Moreover, the frequency of licorice intake was also associated, albeit 
Table 2 Household income, educational level and nutritional habits

\begin{tabular}{|c|c|c|c|c|}
\hline Household income and educational level & Total number & $\begin{array}{l}\text { Alternative medicines } \\
\text { and herbal remedies \% (n) }\end{array}$ & $\begin{array}{l}\text { Ginger consumption } \\
1 \text { st trimester \% (n) }\end{array}$ & $\begin{array}{l}\text { Licorice intake 1st } \\
\text { trimester \% (n) }\end{array}$ \\
\hline \multicolumn{5}{|l|}{ Income in Danish Kroner } \\
\hline$<103,000-200,000$ DKK & 10 & $0.0(0)$ & $0.0(0)$ & $80.0(8)$ \\
\hline 200,000-500,000 DKK & 79 & $24.1(19)$ & $10.1(8)$ & $84.8(67)$ \\
\hline $500,000-800,000$ DKK & 104 & $21.2(22)$ & $11.5(12)$ & $91.3(95)$ \\
\hline$>800,000 \mathrm{DKK}$ & 31 & $32.3(10)$ & $16.1(5)$ & $83.9(26)$ \\
\hline \multicolumn{5}{|l|}{ Educational level } \\
\hline Elementary school & 8 & $12.5(1)$ & $12.5(1)$ & $87.5(7)$ \\
\hline Upper secondary school & 17 & $17.6(3)$ & $5.9(1)$ & $88.2(15)$ \\
\hline Vocational education & 56 & $21.4(12)$ & $7.1(4)$ & $82.1(46)$ \\
\hline Shorter level of education & 29 & $20.7(6)$ & $13.8(4)$ & $89.7(26)$ \\
\hline Bachelor degree & 85 & $24.7(21)$ & $12.9(11)$ & $91.8(78)$ \\
\hline Master degree & 27 & $25.9(7)$ & $14.8(4)$ & $81.5(22)$ \\
\hline
\end{tabular}

Two participants were not included in educational level; one did not have an educational diploma, and one had an educational level not represented by the educational categories

Summary of the socioeconomic status among the women and their use of alternative medicines and herbal remedies with focus on ginger and licorice

Table 3 Consumption of alternative medicine and herbal ailments

\begin{tabular}{|c|c|c|}
\hline Intake of alternative medicine and supplements & $\%(n)$ & Possible risk in pregnancy / recommendations during pregnancy \\
\hline Alternative medicines & $22.7(51)$ & \\
\hline Psyllium Husk Fiber & $6.7(15)$ & $\begin{array}{l}\text { Delayed absorption of other drugs, necessary insulin dosage } \\
\text { adjustment (downward) for diabetics [30] }\end{array}$ \\
\hline Valerian & $0.4(1)$ & Influence on fetal ossification, cytotoxic and mutagen [5] \\
\hline Glucosamines & $0.4(1)$ & No available information \\
\hline Ginger & $11.1(25)$ & $\begin{array}{l}\text { Induce abortion, influence fetal testosterone metabolism and } \\
\text { maternal vaginal bleeding from gestational week } 17[5,31]\end{array}$ \\
\hline Pregnancy tea (raspberry leaves and ginger) & $0.4(1)$ & Antigonadotrophic effects [5] \\
\hline Mint tea & $1.8(4)$ & Emmenagogue properties [30] \\
\hline Cranberry tablets & $0.4(1)$ & Insufficient treatment of UVI [3] \\
\hline Kefir & $0.4(1)$ & Contains small amounts of alcohol (fermented) \\
\hline Kombucha tea & $0.4(1)$ & Contains small amounts of alcohol (fermented) \\
\hline Krauterblüt (herbal iron remedy) & $2.7(6)$ & Iron deficiency due to insufficient supplementation [32] \\
\hline Thyme tea & $0.4(1)$ & Inducing abortion [2] \\
\hline L-lysine & $0.4(1)$ & No available information \\
\hline Green tea & $0.4(1)$ & Contains caffeine [30] \\
\hline Turmeric & $0.4(1)$ & Induces abortion [33] and is cytotoxic [34] \\
\hline Lactic Lactobacillus acidophilus bacteria & $0.9(2)$ & No available information \\
\hline Boldocynara (Boldo, dandelion, mint, artichoke) & $0.4(1)$ & $\begin{array}{l}\text { No available information, but mint has emmenagogue } \\
\text { properties [30] }\end{array}$ \\
\hline Oregano & $0.4(1)$ & No available information \\
\hline Essential (Norwegian remedy) & $0.4(1)$ & No available information \\
\hline MK oil (Linseed, evening primrose, rosehip, caraway) & $0.4(1)$ & $\begin{array}{l}\text { Caraway has emmenagogue properties and spasmolytic effects [30], } \\
\text { evening primrose increases the incidence of prolonged rupture of } \\
\text { membranes, oxytocin augmentation and vacuum extraction [31] }\end{array}$ \\
\hline
\end{tabular}

Overview of the reported use of alternative medicines by the women and an outline of the current recommendation and reported risk aspects in pregnancy from the medical literature 
Table 4 Usages of alternative medicines

\begin{tabular}{|c|c|c|c|}
\hline $\begin{array}{l}\text { Name } \\
\text { Scientific name }\end{array}$ & Ethnomedical use & Verified scientific use & Use in Danish setting \\
\hline $\begin{array}{l}\text { Artichoke, in Boldocynara } \\
\text { Cynara scolymus }\end{array}$ & $\begin{array}{l}\text { Loss of appetite, dyspeptic complains, and } \\
\text { prophylactic against reemission of gallstones } \\
\text { and as a tonic in convalescence [30] }\end{array}$ & No data of clinical efficacy ${ }^{a}$ & Against flatulence $^{c}$ \\
\hline $\begin{array}{l}\text { Boldo, in Boldocynara } \\
\text { Peumus boldus }\end{array}$ & Dyspeptic complaints [30] & No data of clinical efficacy ${ }^{\text {a }}$ & Against flatulence $^{c}$ \\
\hline $\begin{array}{l}\text { Brown Kelp, in Krauterblüt }{ }^{\oplus} \\
\text { Macrocystis pyrifera }\end{array}$ & $\begin{array}{l}\text { Weight reduction, against hypertension } \\
\text { and anemia in pregnancy [30] }\end{array}$ & No clinical data & $\begin{array}{l}\text { Ensure a good supply of iron, } \\
\text { riboflavin, pyridoxines, cobalamin } \\
\text { and vitamin } C^{c}\end{array}$ \\
\hline $\begin{array}{l}\text { Caraway, in MK oil } \\
\text { Carum carvi }\end{array}$ & $\begin{array}{l}\text { Gastrointestinal cramps, flatulence, feelings } \\
\text { of fullness, improve lactation, an } \\
\text { emmenagogue [30] }\end{array}$ & Insufficient data of clinical efficacy ${ }^{a}$ & $\begin{array}{l}\text { Anti-ageing properties with vital } \\
\text { vitamins, minerals and bioflavonoids }{ }^{c}\end{array}$ \\
\hline $\begin{array}{l}\text { Cascarilla, in Krauterblüt }{ }^{\circledR} \\
\text { Croton eluteria }\end{array}$ & $\begin{array}{l}\text { Digestive disorders, diarrhea and } \\
\text { vomiting [30] }\end{array}$ & No clinical data & $\begin{array}{l}\text { Ensure a good supply of iron, } \\
\text { riboflavin, pyridoxines, cobalamin } \\
\text { and vitamin } C^{c}\end{array}$ \\
\hline $\begin{array}{l}\text { Cranberry } \\
\text { Vaccinium macrocarpon }\end{array}$ & $\begin{array}{l}\text { Against urinary tract irritation, gout, } \\
\text { rheumatism and calculus [30] }\end{array}$ & Mixed data of clinical efficacy [35] & $\begin{array}{l}\text { Prevention and treatment of lighter, } \\
\text { recurrent urinary tract infections }{ }^{b}\end{array}$ \\
\hline $\begin{array}{l}\text { Dandelion, in Boldocynara } \\
\text { Taraxacum officinale }\end{array}$ & $\begin{array}{l}\text { Acute mastitis, urinary disorders, } \\
\text { chronic ulcers, tuberculosis, flatulence, }\end{array}$ & No data of clinical efficacy ${ }^{a}$ & Against flatulence ${ }^{c}$ \\
\hline
\end{tabular}

Evening primrose, in MK oil Oenothera biennis

Fennel, in Krauterblüt ${ }^{\oplus}$ Foeniculum vulgare

Field Horsetail, in Krauterblüt ${ }^{\circledast}$ Equisetum arvense

Garden angelica, in Krauterblüt ${ }^{\oplus}$ Angelica archangelica

\section{Ginger \\ Zingiber officinale}

Glucosamines

Green tea

Camellia sinensis

Hibiscus, in Krauterblüt ${ }^{\oplus}$

Hibiscus sabdariffa

Kefir (fermented probiotic milk product)

Kombucha tea

Lactic Lactobacillus acidophilus bacteria (fermented probiotic milk product) chronic ulcers, tuberculosis, flatulence, colic, kidney disease, gout, jaundice and biliary stones [30]

Neurodermatitis, premenstrual syndrome, dietary aid, high cholesterol levels, menopausal hot flashes, mastalgia and treatment of hyperactivity in children [30]

Peptic discomforts, disorders of the gastrointestinal tract, feeling of fullness, flatulence and catarrh of the upper respiratory tract [30]

Tuberculosis, catarrh in the kidney and bladder regions, a hematostatic for profuse menstruation, nasal, pulmonary and gastric hemorrhages, rheumatic diseases, gout, poorly healing wounds, swelling, fractures, frostbite and loss of hair [30]

Used against loss of appetite, dyspeptic and menstruation complaints, liver and biliary duct conditions, coughs and bronchitis [30]

Used as a carminative, expectorant, and astringent. To treat colds, shortness of breath, nausea, vomiting, dyspeptic symptoms and pharyngitis [30]

Originally used in veterinary medicine

Stomach disorders, nausea, migraine, symptoms of fatigue, vomiting, diarrhea, cardiac and circulatory conditions, states of agitation, states of depression, pain, fever and fatigue [30]

Diuretic, mild laxative, treatment of hypertension, pyrexia, cough, colds, malaria and skin inflammations [36]

Limited data

Weight loss and anticancer properties [38] Introduced in the early twentieth century. To normalize the bacterial flora in the gut.

$$
\text { efficacy [37] }
$$

Limited data

\section{No clinical data}

Insufficient data of clinical efficacy. However, coumarin-derivatives in Angelica archangelica are

phototoxic ${ }^{\mathrm{a}}$

Limited data

Stimulatory effect ${ }^{a}$ (corroborated with the caffeine content)

Mixed data of clinical efficacy [39]
Anti-ageing properties with vital vitamins, minerals and bioflavonoids ${ }^{c}$

Ensure a good supply of iron, riboflavin, pyridoxines, cobalamin and vitamin $C^{C}$

Ensure a good supply of iron, riboflavin, pyridoxines, cobalamin and vitamin $C^{\mathrm{C}}$

Ensure a good supply of iron, riboflavin, pyridoxines, cobalamin and vitamin $\mathrm{C}^{\mathrm{c}}$

No available data

Prevention and treatment of osteoarthritis ${ }^{c}$

No available data

Ensure a good supply of iron, riboflavin, pyridoxines, cobalamin and vitamin $C^{\mathrm{C}}$

No available data

No available data

Normalization of the intestinal flora ${ }^{b}$ 
Table 4 Usages of alternative medicines (Continued)

\begin{tabular}{|c|c|c|c|}
\hline $\begin{array}{l}\text { Name } \\
\text { Scientific name }\end{array}$ & Ethnomedical use & Verified scientific use & Use in Danish setting \\
\hline $\begin{array}{l}\text { Licorice } \\
\text { Glycyrrhiza glabra }\end{array}$ & $\begin{array}{l}\text { Sore throats, appendicitis, constipation, } \\
\text { and to increase milk production and } \\
\text { micturition [30] }\end{array}$ & Insufficient data of clinical efficacy ${ }^{\mathrm{a}}$ & $\begin{array}{l}\text { Mucous release effect for cough in } \\
\text { shorter periods }\end{array}$ \\
\hline $\begin{array}{l}\text { Linseed, in MK oil } \\
\text { Linum usitatissimum }\end{array}$ & $\begin{array}{l}\text { For coughs, bronchial conditions, } \\
\text { urethritis, diarrhea and gonorrhea [30] }\end{array}$ & $\begin{array}{l}\text { Mixed data of clinical efficacy. } \\
\text { However, effectiveness of treatment } \\
\text { of habitual constipation and softening } \\
\text { of stool is plausible }\end{array}$ & $\begin{array}{l}\text { Anti-ageing properties with vital } \\
\text { vitamins, minerals and } \\
\text { bioflavonoids } s^{c}\end{array}$ \\
\hline L-lysine & Limited data & Limited data & \\
\hline $\begin{array}{l}\text { Mint } \\
\text { Mentha piperita }\end{array}$ & $\begin{array}{l}\text { Nausea, vomiting, morning sickness, } \\
\text { respiratory infections, dysmenorrhea and } \\
\text { colds [30] }\end{array}$ & $\begin{array}{l}\text { Symptomatic relief of digestive } \\
\text { disorders }^{a}\end{array}$ & Indigestion and flatulence $\mathrm{e}^{\mathrm{b}}$ \\
\hline $\begin{array}{l}\text { Nettle, in Krauterblüt } \\
\text { Urtica dioica }\end{array}$ & $\begin{array}{l}\text { Hematogenic, rheumatic remedy, diuretic } \\
\text { [30]. For diabetes, hypertension and } \\
\text { prostate cancer [40] }\end{array}$ & Insufficient data of clinical efficacy ${ }^{a}$ & $\begin{array}{l}\text { Ensure a good supply of iron, } \\
\text { riboflavin, pyridoxines, cobalamin } \\
\text { and vitamin } C^{C}\end{array}$ \\
\hline $\begin{array}{l}\text { Oregano } \\
\text { Origanum vulgare }\end{array}$ & $\begin{array}{l}\text { Colds, fever, cough, vomiting, dyspepsia } \\
\text { painful menstruation, rheumatoid arthritis, } \\
\text { urinary tract disorders, dysentery, jaundice } \\
\text { and malnutrition for children [30] }\end{array}$ & Limited data & No available data \\
\hline $\begin{array}{l}\text { Physillium Husk Fibre } \\
\text { Plantago ovata }\end{array}$ & $\begin{array}{l}\text { Against inflammation of the mucous } \\
\text { membrane in the urogenital and } \\
\text { gastrointestinal tract [30] }\end{array}$ & $\begin{array}{l}\text { Treatment of habitual constipation, } \\
\text { desirable soft stool and adjuvant to } \\
\text { diet in hypercholesterolemia }\end{array}$ & $\begin{array}{l}\text { Against constipation, diarrhea, to } \\
\text { increase fiber intake and adjuvant } \\
\text { to diet in hypercholesteremia }\end{array}$ \\
\hline $\begin{array}{l}\text { Quackgrass, in Krauterblüt }{ }^{\oplus} \\
\text { Agropyron repens }\end{array}$ & Urinary tract infections [30] & No data of clinical efficacy ${ }^{a}$ & $\begin{array}{l}\text { Ensure a good supply of iron, } \\
\text { riboflavin, pyridoxines, cobalamin } \\
\text { and vitamin } C^{C}\end{array}$ \\
\hline Raspberry leavesRubus idaeus & Relieve nausea and induce labour [30] & Insufficient data of clinical efficacy ${ }^{a}$ & No available data \\
\hline Rosehip, in MK oilRosa rugosa & $\begin{array}{l}\text { Disorders in the efferent urinary tract, the } \\
\text { kidneys, kidney stones, rheumatic } \\
\text { conditions, gout, colds, scurvy, febrile } \\
\text { conditions [30] }\end{array}$ & Limited data & $\begin{array}{l}\text { Anti-ageing properties with vital } \\
\text { vitamins, minerals and } \\
\text { bioflavonoids } s^{c}\end{array}$ \\
\hline $\begin{array}{l}\text { Spinach, in Krauterblüt } \\
\text { Spinacia oleracea }\end{array}$ & $\begin{array}{l}\text { Ailments of the gastrointestinal tract and } \\
\text { blood generating [30] }\end{array}$ & Limited data & $\begin{array}{l}\text { Ensure a good supply of iron, } \\
\text { riboflavin, pyridoxines, cobalamin } \\
\text { and vitamin } C^{C}\end{array}$ \\
\hline $\begin{array}{l}\text { Thyme } \\
\text { Thymus vulgaris }\end{array}$ & $\begin{array}{l}\text { Catarrh of the upper respiratory tract, } \\
\text { asthma, laryngitis, cough, gastritis and } \\
\text { dyspepsia [30] }\end{array}$ & No data of clinical efficacy ${ }^{a}$ & $\begin{array}{l}\text { Expectorate by productive cough in } \\
\text { combination with Primula veris }\end{array}$ \\
\hline $\begin{array}{l}\text { Turmeric } \\
\text { Curcuma longa }\end{array}$ & Dyspeptic disorders and inflammations [30] & No data of clinical efficacy ${ }^{a}$ & No available data \\
\hline $\begin{array}{l}\text { Yarrow, in Krauterblüt } \\
\text { Achillea millefolium }\end{array}$ & $\begin{array}{l}\text { Laxative and treatments against bleeding } \\
\text { hemorrhoids, menstrual complaints and } \\
\text { gynecological agents [30] }\end{array}$ & No data of clinical efficacy ${ }^{a}$ & $\begin{array}{l}\text { Ensure a good supply of iron, } \\
\text { riboflavin, pyridoxines, cobalamin } \\
\text { and vitamin } C^{C}\end{array}$ \\
\hline $\begin{array}{l}\text { Wormwood, in Krauterblüt }{ }^{\bullet} \\
\text { Artemisia absinthium }\end{array}$ & $\begin{array}{l}\text { Ailments of gastrointestinal tract, liver } \\
\text { disorders, bloating, anemia, irregular } \\
\text { menstruation, intermittent fever, loss of } \\
\text { appetite and worm infestation [30] }\end{array}$ & No data of clinical efficacy ${ }^{a}$ & $\begin{array}{l}\text { Ensure a good supply of iron, } \\
\text { riboflavin, pyridoxines, cobalamin } \\
\text { and vitamin } C^{C}\end{array}$ \\
\hline
\end{tabular}

${ }^{\mathrm{a}}$ According to scientific rapports by European Medicines Agency (EMA)

${ }^{\mathrm{b}}$ Approved by the Danish Medicines Agency

Please note that in a Danish context an herbal remedy can only be sold if approved by the authorities. However, this approval does not demand any scientific evidence and all though the remedies can only be advertised according to their approval they are sold freely and may be used for other purposes 'Not approved as an herbal remedy. Therefore, stating manufacturers own clarification of remedy on the Danish market

Overview of the common ethnomedical indications and possible scientific verified use concerning the reported use of alternative medicines and their potential indication for use in a Danish setting

not significantly, with reduced birthweight (see Fig. 1). Differences in mean blood pressures between women reporting a mean daily intake of licorice $(123 \mathrm{mmHg}, 95 \%$ CI: $116-130 \mathrm{mmHg}$ ) and women reporting rare or no intake of licorice $(119 \mathrm{mmHg}, 95 \% \mathrm{CI}: 117-121 \mathrm{mmHg}$ ) were significantly associated with increased maternal systolic blood pressure $(p=0.04)$, estimated via one-tailed
Mann-Whitney testing based on the known effects of licorice on blood pressure (see Table 5).

\section{Discussion}

The main finding of this cohort study of Danish pregnant women was that $23 \%$ reported using alternative medicines, with ginger products being by far the most 


\section{Prenatal exposure to licorice and birthweight}

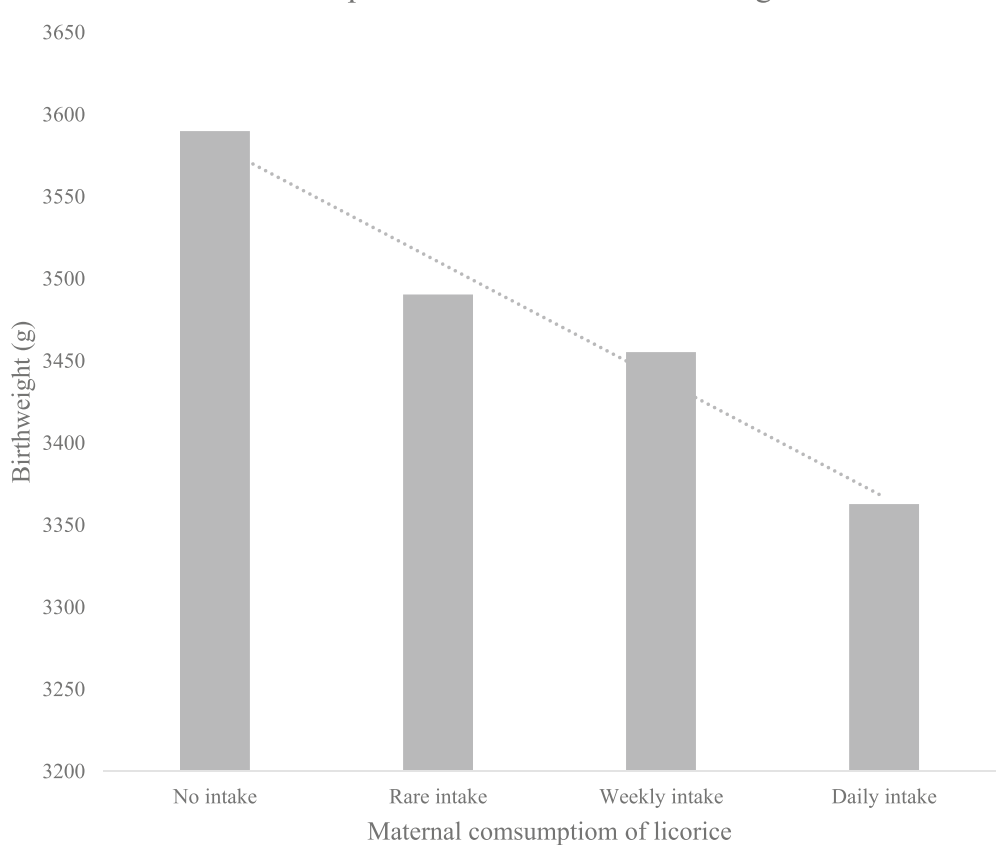

Fig. 1 Association between birthweight and prenatal exposure to maternal licorice consumption. Maternal consumption of licorice showed an association with a reduced birthweight. Mean birthweight $3590 \mathrm{~g}, 95 \% \mathrm{Cl}: 3327-3853 \mathrm{~g}$ in the group with no intake ${ }^{\mathrm{A}}$, mean birthweight $3490 \mathrm{~g}$, 95\% Cl: $3392-3589 \mathrm{~g}(p=0.62)$ in the group with a rare intake, mean birthweight $3455 \mathrm{~g}, 95 \% \mathrm{Cl}: 3335-3575 \mathrm{~g}(p=0.35)$ in the group with a weekly intake vs. mean birthweight $3363 \mathrm{~g}, 95 \% \mathrm{Cl}: 3010-3716 \mathrm{~g}(p=0.29)$ in the group with a daily intake. ${ }^{A}$ Reference group

popular item. Furthermore, $87 \%$ reported consuming licorice, with $7 \%$ reporting daily use.

Performing the study in an unbiased manner where the eligible population was representative of the entire population in the geographic area, and achieving an overall participation rate of $76 \%$, strengthen the value and validity of the findings. Notably, we cannot exclude that selection bias occurred, as the women had to accept participation. However, ultra-performance liquid chromatography with high-resolution time-of-flight mass spectrometry (UPLC-HR-TOFMS) analysis of the pharmacological content of the blood samples from the same cohort (Volqvartz and Vestergaard et al. in prep) indicates a high degree of consistence between results from this cohort and a similar UPLC-HR-TOFMS analysis of unselected, unbiased pregnant women from the same region performed by Aagaard and co-workers [13]. Also, the organisation of the maternal care system supports that all women from all parts of society attends the same, free-of-charge prenatal diagnostic system. On the other hand, limiting our study to one single interview means we did not assess all exposures occurring in pregnancy and, the size of the cohort limits the power to demonstrate possible associations between exposure and adverse obstetric outcomes in particular if the exposures are rare. However, by asking the women specifically if ginger or other substances were used do to pregnancy related nausea or for other reasons we obtained indication of the duration of the use.

Table 5 Maternal blood pressure at gestational week 29 in relation to licorice consumption

\begin{tabular}{lllll}
\hline Licorice consumption & BMI Mean, 95\% Cl & $\begin{array}{l}\text { Systolic blood pressure mmHg } \\
\text { Mean, 95\% Cl }\end{array}$ & $\begin{array}{l}\text { Diastolic blood pressure mmHg } \\
\text { Mean, 95\% Cl }\end{array}$ & $\begin{array}{c}P \text {-value systolic/diastolic } \\
\text { Daily }\end{array}$ \\
Weekly & $27.44(23.91-30.97)$ & $122.81(116.01-129.61)$ & $75.06(69.86-80.26)$ & $0.04 / 0.51^{\mathrm{b}}$ \\
Rarely $^{\mathrm{a}}$ & $27.41(26.04-28.77)$ & $119.37(116.62-122.12)$ & $75.35(73.53-77.18)$ & $0.34 / 0.42^{\mathrm{b}}$ \\
Never $^{\mathrm{a}}$ & $25.81(24.81-26.81)$ & $118.82(116.37-121.27)$ & $75.82(74.10-77.53)$ & \\
\hline
\end{tabular}

aeference groups

${ }^{\mathrm{b} O n e-t a i l e d}$ Mann-Whitney test

Among the women reporting daily consumption of licorice in first trimester, the measured blood pressure later in pregnancy was significant higher than the women who reported a rarely or no intake 
Finally, we did not specifically inquire regarding the intake of red-clover-containing pregnancy tonics, which might explain why this was not mentioned by any participant. Notably, red clover is rich in phytoestrogens [14], and prenatal exposure is suspected to have deleterious effects on the developing male reproductive system; knowledge of the red-clover use among our subjects would thus be valuable. Analysis of 7928 boys in the cohort of "The Avon Longitudinal Study of Parents and Children" (ALSPAC) found that a maternal vegetarian diet rich in phytoestrogens in pregnancy was associated with an increased risk of hypospadias [15].

The fraction (23\%) of pregnant women taking alternative medicines in this Danish study is relatively high compared to previous studies in Sweden (4\%), Finland (9\%), Norway (17\%), and Iceland (35\%) [3], but not compared to a number of non-Nordic countries (29\%) [3]. However, the fraction appears lower than that among non-pregnant Danish pre-surgical patients of both genders (50\%) [16]. The comparison of these studies is limited to some extent by different study designs and different definitions of alternative medicine. However, the positive associations with household income and education level is consistent across several studies [1]. With the size of this study, assessing specific adverse effects on fetal development might not be possible even with our focus on the time of organogenesis. However, studies of the Danish National Birth Cohort have found a higher risk for malformations after prenatal exposure to St. John's wort [17]. This herbal medicine is a "natural anti-depressant" known to affect the serotonin system in ways similar to conventional antidepressants, which is a potential safety concern in pregnancy. With the high prevalence of users of alternative medicines identified in this study, further studies into the teratogenic effects of other exposures are warranted.

In particular, it appears important to focus on the use of ginger products among pregnant women. In Denmark, supermarkets expect to double the selling of ginger shots in coming years [18], even though $77 \%$ of the ginger consumers in our study did not declare their intake to be caused by a need to relieve symptoms. Ginger, or its active compound 6-gingerol (see Fig. 2) interacts with the cytochrome P450 system (e.g., CYP3A4, CYP2C9) [19] and fetal testosterone metabolism [20], thus serving as a potential teratogenic item. Furthermore, a cohort study from Korea showed 4 stillbirths among 159 singleton-pregnancy women receiving dried ginger $(\mathrm{OR}=7.8 ; 95 \%$ CI 2.9-21) compared to the general population [10]. In addition, ginger decreases platelet aggregation, which may increase the risk of post-partum bleeding.

Additionally, the high use of licorice among pregnant women in Denmark deserves further attention. Regular

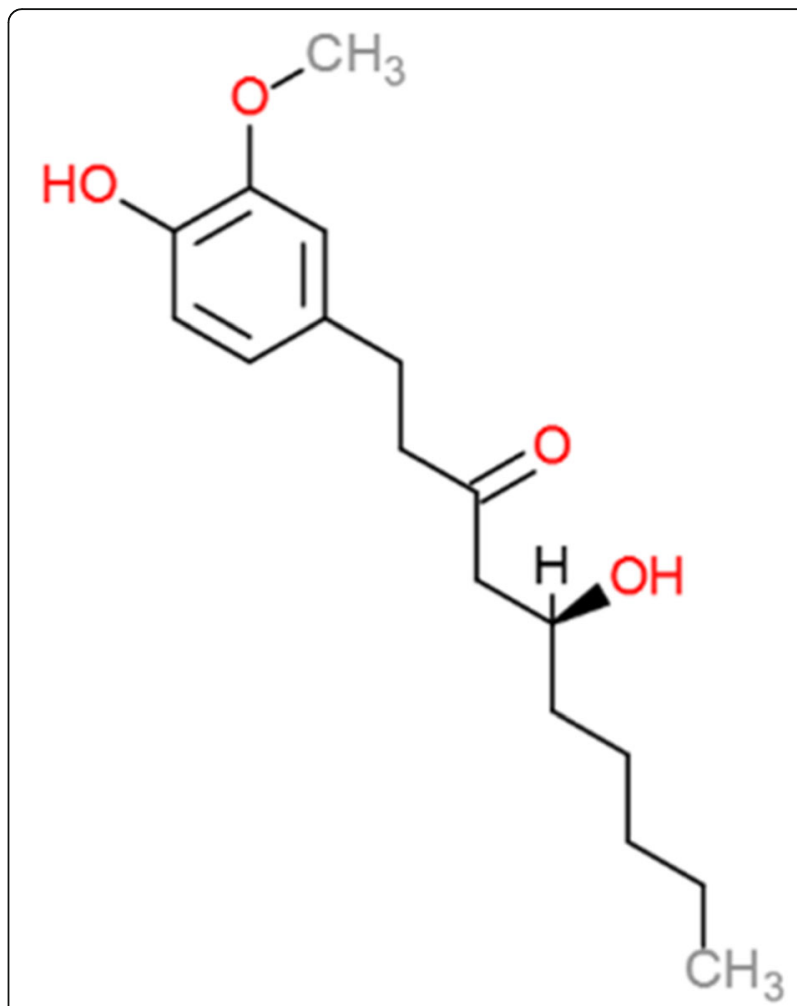

Fig. 2 The chemical structure of 6-gingerols, the main active constituent of ginger, Zingiber officinale. Modified after Qui et al. [19]. 6-gingerol is derived from the phenylalanine pathway and has potential to be antiseptic, to have anti-cancer properties and reducing nausea and migraine

consumption of licorice - and hence the active compound glycyrrhizin (see Fig. 3) - inhibits the 11- $\beta$-hydroxysteroid dehydrogenase type 2 (11- $\beta$-HSD2) enzyme, thereby activating cortisol and generating hypokalaemic hypertension [21]. Notably, we observed a minor increase in maternal systolic blood pressure $(p=$ 0.04) and lower birthweights among children exposed to frequent maternal intake of licorice. The downregulation of $11-\beta-$ HSD2 in the placenta may contribute to several of the pathways leading to an increased risk of preeclampsia [21], miscarriage [22], preterm birth [23], toxicological effects [24], and lower intelligence quotient, poor memory and increased risk of attention deficit in the child [25]. Furthermore, the phytoestrogen found in licorice, glabridin, might explain the pubertal advancement seen in girls prenatally exposed to licorice $[25,26]$.

In this study, we characterized lifestyle habits at the end of the first trimester of pregnancy, which is a very critical period of organogenesis [27]. Notably, several studies into the Developmental Origins of Health and Disease Hypothesis (DOHaD) have shown that different effect occur in responds to reprogramming at different part of the pregnancy (for a review see Roseboom 


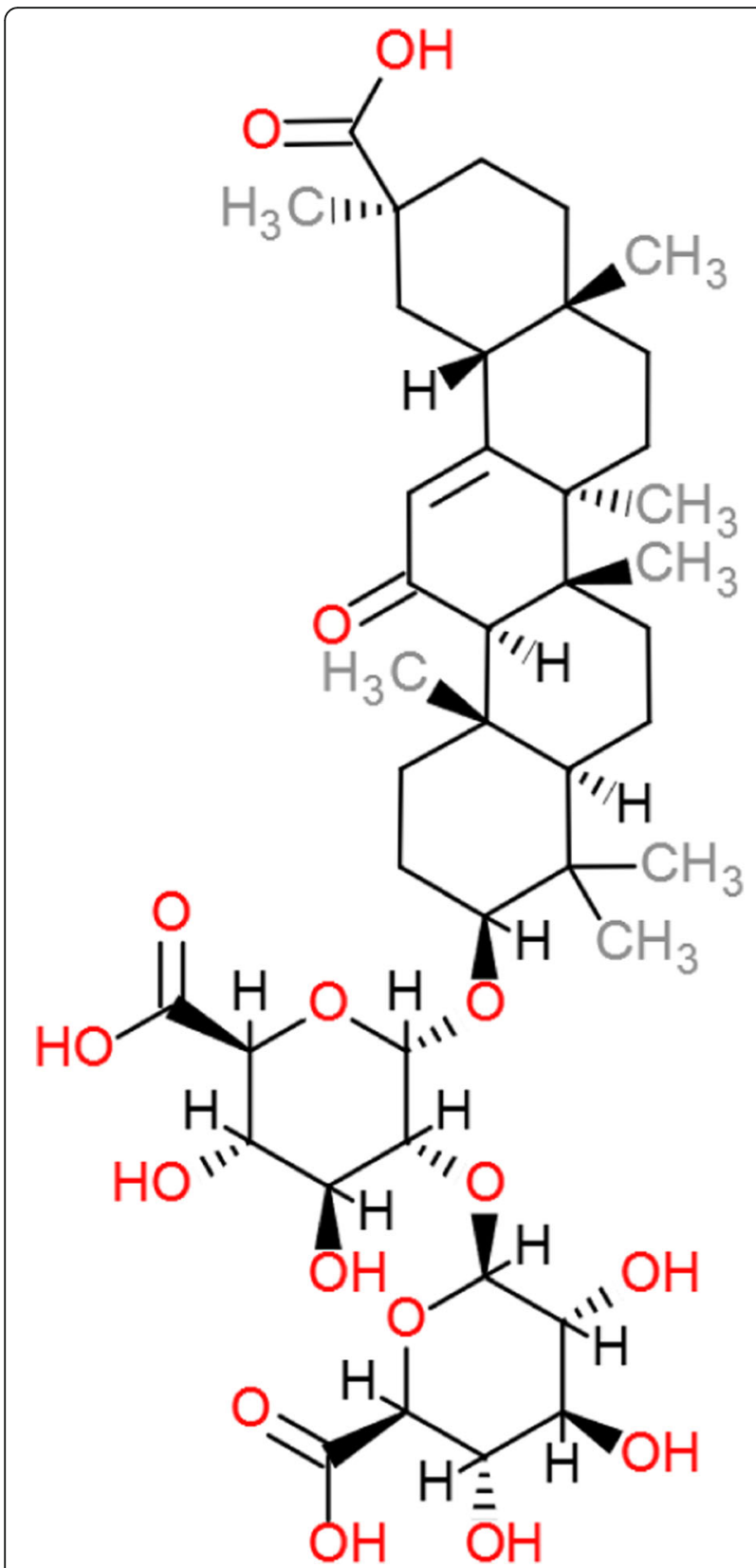

Fig. 3 The chemical structure of licorice, glycyrrhizin. Modified after Li et al. [29]. Glycyrrhizin is the sweet component of licorice which is metabolized to glycyrrhetinic acid. Glycyrrhizin has potential to be anti-inflammatory. However, it also has the ability to cause retention of sodium and loss of potassium, increasing blood pressure, causing edema and affecting the renin-angiotensin-aldosterone system

and coworkers [28]). Further studies should be aimed at including additional information of the habits in later pregnancy and expand the number of participants as it cannot be excluded that changes in habits occur during pregnancy which could also affect offspring health.

\section{Conclusions}

In a Danish context, ginger and liquorice are commonly ingested by pregnant women as are alternative medications. Based on our results and the discussion above, we recommend that health providers actively seek to increase their knowledge of the eating habits and alternative medicine use of pregnant women to avoid unnecessary health risk in pregnancy.

\section{Additional files}

Additional file 1: Table S2. Overview of pregnancy outcomes at birth. (DOCX $13 \mathrm{~kb}$ )

Additional file 2: Figure S1. Flow diagram of participant involvement. (DOCX $24 \mathrm{~kb}$ )

Additional file 3: Table S1. Summary of the relationship between parity and maternal lifestyle among the pregnant women. (DOCX $13 \mathrm{~kb}$ )

\section{Abbreviations}

BMI: Body Mass Index; DOHaD: Developmental Origins of Health and Disease Hypothesis; OTC: Over-The-Counter; UPLC-HR-TOFMS: Ultra-Performance Liquid Chromatography with High-Resolution Time-Of-Flight Mass Spectrometry Analysis

\section{Acknowledgements}

We would like to thank all doctors, midwives, health care workers and secretaries for their collaboration, financial support and for taking the time to help with the completion of this study at the Department of Obstetrics and Gynecology and the Research Unit, Randers Regional Hospital.

\section{Funding}

This study was financially funded by the A.P. Møller Foundation, the Grosserer L. F. Foghts Foundation, the Foundation of the 1870s and the Linex Foundation. These Foundations had no role in the design of the study and collection, analysis, and interpretation of data and in writing the manuscript.

\section{Availability of data and materials}

The datasets used and analyzed during the current study are available from the corresponding author on reasonable request.

\section{Authors' contributions}

TV and ALV participated in the design of the study and drafted the manuscript with inputs from $\mathrm{AL}$ and $\mathrm{PB}$. TV conducted the analyses in collaboration with ALV, NU, AL and PB. SKA, MFA, IL, NU, AL, PB all participated in the design of the study, interpretation of data and revision of the manuscript. All authors read and approved the final manuscript.

\section{Ethics approval and consent to participate}

All participants gave oral and written informed consent before participating. The study was approved by the Regional Scientific Ethical Committee (VEK 1-10-72-75-16).

\section{Consent for publication}

Not applicable.

\section{Competing interests}

The authors declare that they have no competing interests.

\section{Publisher's Note}

Springer Nature remains neutral with regard to jurisdictional claims in published maps and institutional affiliations.

\section{Author details}

'Department of Obstetrics and Gynecology, Randers Regional Hospital, Randers, Denmark. 'Department of Biomedicine, Pharmacology, Aarhus University, Aarhus, Denmark. ${ }^{3}$ Section for Forensic Chemistry, Department of Forensic Medicine, Aarhus University, Aarhus, Denmark. ${ }^{4}$ Department of 
Pathology, Vidant Medical Center, Greenville, North Carolina, USA. ${ }^{5}$ Department of Obstetrics and Gynecology, Aarhus University Hospital, Aarhus, Denmark.

Received: 21 August 2018 Accepted: 19 December 2018 Published online: 05 January 2019

\section{References}

1. Hall HG, Griffiths DL, McKenna LG. The use of complementary and alternative medicine by pregnant women: a literature review. Midwifery. 2011;27(6):817-24

2. Kennedy DA, Lupattelli A, Koren G, Nordeng H. Safety classification of herbal medicines used in pregnancy in a multinational study. BMC Complement Altern Med. 2016;16:102.

3. Kennedy DA, Lupattelli A, Koren G, Nordeng H. Herbal medicine use in pregnancy: results of a multinational study. BMC Complement Altern Med. 2013;13(1):355

4. Danish Medicines Agency. Guidance on marketing authorization for herbal remedies (Markedsføringstilladelse til naturlægemidler) [Internet]. Lægemiddelstyrelsen. [cited 2017 Nov 30]. Available from: https:// laegemiddelstyrelsen.dk/da/godkendelse/godkendelse-af-medicin/ markedsfoeringstilladelse/ansoegning-om-markedsfoeringstilladelse/ markedsfoeringstilladelse-til-naturlaegemidler/

5. Mills E, Dugoua J-J, Perri D. Herbal medicines in pregnancy and lactation: an evidence-based approach. 1st edition. United Kingdom: CRC Press. Taylor \& Francis Group; 2006

6. McLay JS, Izzati N, Pallivalapila AR, Shetty A, Pande B, Rore C, et al. Pregnancy, prescription medicines and the potential risk of herb-drug interactions: a cross-sectional survey. BMC Complement Altern Med. 2017;17(1):543.

7. Frawley J, Adams J, Steel A, Broom A, Gallois C, Sibbritt D. Women's use and self-prescription of herbal medicine during pregnancy: an examination of 1,835 pregnant women. Womens Health Issues Off Publ Jacobs Inst Womens Health. 2015;25(4):396-402.

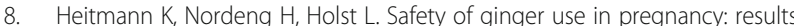
from a large population-based cohort study. Eur J Clin Pharmacol. 2013; 69(2):269-77.

9. Marx W, McKavanagh D, McCarthy AL, Bird R, Ried K, Chan A, et al. The Effect of Ginger (Zingiber officinale) on Platelet Aggregation: A Systematic Literature Review. PLoS ONE [Internet]. 2015 [cited 2017 Nov 23];10(10). Available from: https://www.ncbi.nlm.nih.gov/pmc/articles/PMC4619316/

10. Choi JS, Han JY, Ahn HK, Lee SW, Koong MK, Velazquez-Armenta EY, et al. Assessment of fetal and neonatal outcomes in the offspring of women who had been treated with dried ginger (Zingiberis rhizoma siccus) for a variety of illnesses during pregnancy. J Obstet Gynaecol J Inst Obstet Gynaecol. 2015;35(2):125-30.

11. Raveendra KR, Jayachandra, Srinivasa V, Sushma KR, Allan JJ, Goudar KS, et al. An Extract of Glycyrrhiza glabra (GutGard) Alleviates Symptoms of Functional Dyspepsia: A Randomized, Double-Blind, Placebo-Controlled Study. Evid-Based Complement Altern Med ECAM [Internet]. 2012 [cited 2018 Nov 6];2012. Available from: https://www.ncbi.nlm.nih.gov/pmc/ articles/PMC3123991/

12. Okuda-Tanino A, Sugawara D, Tashiro T, Iwashita M, Obara Y, Moriya T, et al. Licochalcones extracted from Glycyrrhiza inflata inhibit platelet aggregation accompanied by inhibition of COX-1 activity. PLoS One. 2017;12(3):e0173628.

13. Aagaard SK, Larsen A, Andreasen MF, Lesnikova I, Telving R, Vestergaard AL, et al. Prevalence of xenobiotic substances in first-trimester blood samples from Danish pregnant women: a cross-sectional study. BMJ Open. 2018;8(3): e018390.

14. Humfrey CD. Phytoestrogens and human health effects: weighing up the current evidence. Nat Toxins. 1998;6(2):51-9.

15. North K, Golding J. A maternal vegetarian diet in pregnancy is associated with hypospadias. The ALSPAC study team. Avon longitudinal study of pregnancy and childhood. BJU Int. 2000;85(1):107-13.

16. Vaabengaard P, Clausen LM. Surgery patients' intake of herbal preparations and dietary supplements. Ugeskr Laeger. 2003;165(35):3320-3.

17. Kolding L, Pedersen LH, Henriksen TB, Olsen J, Grzeskowiak LE. Hypericum perforatum use during pregnancy and pregnancy outcome. Reprod Toxicol Elmsford N. 2015;58:234-7.

18. Bleeg MT. Danskerne drikker ingefærshots som aldrig før: Det er unødvendigt TV 2. livsstil.tv2.dk [Internet]. 2016 [cited 2017 Nov 23]; Available from: http:// livsstil.tv2.dk/sundhed/2016-04-19-danskerne-drikker-ingefaershots-som-aldrigfoer-det-er-unoedvendigt

19. Qiu J-X, Zhou Z-W, He Z-X, Zhang X, Zhou S-F, Zhu S. Estimation of the binding modes with important human cytochrome P450 enzymes, drug interaction potential, pharmacokinetics, and hepatotoxicity of ginger components using molecular docking, computational, and pharmacokinetic modeling studies. Drug Des Devel Ther. 2015;9:841-66.

20. Søndergaard K. [Ginger, pregnancy nausea and possible fetal injuries (testosterone effect)]. Ugeskr Laeger. 2008;170(5):359; author reply 359

21. Räikkönen $K$, Pesonen A-K, Heinonen $K$, Lahti J, Komsi N, Eriksson JG, et al. Maternal licorice consumption and detrimental cognitive and psychiatric outcomes in children. Am J Epidemiol. 2009;170(9):1137-46.

22. Cuzzolin L, Francini-Pesenti F, Verlato G, Joppi M, Baldelli P, Benoni G. Use of herbal products among 392 Italian pregnant women: focus on pregnancy outcome. Pharmacoepidemiol Drug Saf. 2010;19(11):1151-8.

23. Strandberg TE, Järvenpää AL, Vanhanen H, McKeigue PM. Birth outcome in relation to licorice consumption during pregnancy. Am J Epidemiol. 2001; 153(11):1085-8

24. Nazari S, Rameshrad M, Hosseinzadeh H. Toxicological effects of Glycyrrhiza glabra (licorice): a review. Phytother Res PTR. 2017;31(11):1635-50.

25. Räikkönen K, Martikainen S, Pesonen A-K, Lahti J, Heinonen K, Pyhälä R, et al Maternal licorice consumption during pregnancy and pubertal, cognitive, and psychiatric outcomes in children. Am J Epidemiol. 2017;185(5):317-28.

26. Simmler C, Pauli GF, Chen S-N. Phytochemistry and biological properties of glabridin. Fitoterapia. 2013;90:160-84.

27. Roseboom TJ, van der Meulen JH, Ravelli AC, Osmond C, Barker DJ, Bleker OP. Effects of prenatal exposure to the Dutch famine on adult disease in later life: an overview. Mol Cell Endocrinol. 2001;185(1-2):93-8.

28. Roseboom TJ, Painter RC, van Abeelen AFM, Veenendaal MVE, de Rooij SR. Hungry in the womb: what are the consequences? Lessons from the Dutch famine. Maturitas. 2011;70(2):141-5.

29. Li J, Cao H, Liu P, Cheng G, Sun M. Glycyrrhizic Acid in the Treatment of Liver Diseases: Literature Review. BioMed Res Int [Internet]. 2014 [cited 2018 Nov 30];2014. Available from: https://www.ncbi.nlm.nih.gov/pmc/articles/ PMC4052927/

30. Fleming T, editor. PDR for herbal medicines. 2., rev. ed. Montvale, N.J: Medical Economics Co: 2000.

31. Dante G, Bellei G, Neri I, Facchinetti F. Herbal therapies in pregnancy: what works? Curr Opin Obstet Gynecol. 2014;26(2):83-91.

32. Holst $L$, Nordeng $H$, Haavik $S$. Use of herbal drugs during early pregnancy in relation to maternal characteristics and pregnancy outcome. Pharmacoepidemiol Drug Saf. 2008;17(2):151-9.

33. de Boer HJ, Cotingting C. Medicinal plants for women's healthcare in Southeast Asia: a meta-analysis of their traditional use, chemical constituents, and pharmacology. J Ethnopharmacol. 2014;151(2):747-67.

34. Huang F-J, Lan K-C, Kang H-Y, Liu Y-C, Hsuuw Y-D, Chan W-H, et al. Effect of curcumin on in vitro early post-implantation stages of mouse embryo development. Eur J Obstet Gynecol Reprod Biol. 2013:166(1):47-51.

35. National Center for Complementary and Integrative Health. Cranberry [Internet]. NCCIH. 2011 [cited 2018 Nov 13]. Available from: https://nccih.nih. gov/health/cranberry

36. Abat JK, Kumar S, Mohanty A. Ethnomedicinal, Phytochemical and Ethnopharmacological Aspects of Four Medicinal Plants of Malvaceae Used in Indian Traditional Medicines: A Review. Medicines [Internet]. 2017 [cited 2018 Nov 13];4(4). Available from: https://www.ncbi.nlm.nih. gov/pmc/articles/PMC5750599/

37. Serban C, Sahebkar A, Ursoniu S, Andrica F, Banach M. Effect of sour tea (Hibiscus sabdariffa L.) on arterial hypertension: a systematic review and meta-analysis of randomized controlled trials. J Hypertens. 2015;33(6):1119-27.

38. Teoh AL, Heard G, Cox J. Yeast ecology of Kombucha fermentation. Int J Food Microbiol. 2004;95(2):119-26.

39. National Center for Complementary and Integrative Health. Probiotics: In Depth [Internet]. NCCIH. 2011 [cited 2018 Nov 13]. Available from: https:// nccih.nih.gov/health/probiotics/introduction.htm

40. El Haouari M, Rosado JA. Phytochemical, Anti-Diabetic And Cardiovascular Properties Of Urtica dioica L. (Urticaceae): A Review. Mini Rev Med Chem. 2019;19(1):63-71. Epub ahead of print 